\title{
Trade Policy Analysis in the Presence of Duty Drawbacks*
}

\author{
Elena Ianchovichina* \\ The World Bank
}

\begin{abstract}
World Bank Policy Research Working Paper 3312, May 2004
The Policy Research Working Paper Series disseminates the findings of work in progress to encourage the exchange of ideas about development issues. An objective of the series is to get the findings out quickly, even if the presentations are less than fully polished. The papers carry the names of the authors and should be cited accordingly. The findings, interpretations, and conclusions expressed in this paper are entirely those of the authors. They do not necessarily represent the view of the World Bank, its Executive Directors, or the countries they represent. Policy Research Working Papers are available online at http://econ.worldbank.org.
\end{abstract}

\footnotetext{
* This paper is a product of the Economic Policy Division, Poverty Reduction and Economic Management Network. I would like to thank William Martin for providing inspiration for this study and comments on earlier drafts of the paper. I am grateful to Thomas Hertel, Terrie Walmsley, and Deepak Bhattasali for their valuable comments, and to Li Yan for helpful advice and data on import tariffs and duty exemptions.

* Elena Ianchovichina, MC4-248, World Bank, 1818 H Street, N.W., Washington DC 20433. Tel: +1202-458-8910. Fax: +1-202-522-1557. Email: eianchovichina@worldbank.org.
} 


\title{
Trade Policy Analysis in the Presence of Duty Drawbacks
}

\author{
Elena Ianchovichina
}

\begin{abstract}
Duty drawback schemes, which typically involve a combination of duty rebates and exemptions, are a feature of many countries' trade regimes. They are used in highly protected developing economies as means of providing exporters with imported inputs at world prices, thus increasing their competitiveness, while maintaining the protection on the rest of the economy. In China, duty exemptions have been central to the process of trade reform and have led to a tremendous increase in processed exports utilizing imported materials. Despite the widespread use and importance of duty drawbacks, these "new trade liberalization" instruments have been given relatively little attention in empirical multilateral trade liberalization studies. This paper presents an empirical multi-region general equilibrium model, in which the effects of policy reform are differentiated based on the trade orientation of the firms. The model is useful for analyzing trade liberalization in the presence of duty drawbacks, assessing whether countries should introduce or abolish these types of arrangements, and evaluating the impact of improved duty drawback system administration. The analysis shows that failure to account for duty exemptions in the case of China's recent WTO accession will overstate the increase in China's trade flows by 40 percent, welfare by 15 percent, and exports of selected sectors by as much as 90 percent. The magnitude of the bias depends on the level of pre-intervention tariffs and the size of tariff cuts - the larger the initial distortions and tariff reductions, the larger the bias when duty drawbacks are ignored. The bias in the estimates of China's real GDP, trade flows and welfare changes due to WTO accession increases more than three times when China's pre-intervention tariffs are raised from their 1997 levels to the much higher 1995 levels. These results suggest that trade liberalization studies, focusing on economies in which protection is high, import concessions play an important role and planned tariff cuts are deep, must treat duty drawbacks explicitly in order to avoid serious errors in their estimates of sectoral output, trade flows and welfare changes.
\end{abstract}

JEL classification: F11; F13; D58

Key words: Duty drawbacks; Export processing; Duty exemptions; China; General Equilibrium 


\section{Trade Policy Analysis in the Presence of Duty Drawbacks}

\section{Introduction}

Duty drawback schemes, which typically involve a combination of duty rebates and exemptions, are a feature of many countries' trade regimes. They are used in highly protected developing economies as means of providing exporters with imported inputs at world prices, and thus increasing their competitiveness, while maintaining the protection on the rest of the economy. Duty drawback programs have been used with varied degrees of success. While in many countries duty drawbacks have not been implemented successfully, largely due to administrative weaknesses, in others these schemes have been very effective in opening up export-oriented sectors by overriding existing protection. In China, duty exemptions at the point of entry have been an essential part of the country's export processing system and trade reform process.

The legal framework for China's export processing (EP) system was introduced in 1979 in order to overcome the anti-export bias created by state-managed exchange rate and pricing policies. In the pre-reform era, exchange rates, indirect trade policy instruments such as tariffs, and relative prices had little influence on the magnitude and commodity composition of China's foreign trade. Firms producing for export sold their products to foreign trade companies at officially established domestic prices, fixed in domestic currency. Export producers did not get the foreign exchange income from the sale of their products on international markets, and thus had little incentive to expand production of goods for which foreign demand was strong (Lardy 2002). The prices of imports also distorted the distribution of resources in the economy. Approximately 80 percent of imports were sold in China at prices similar to those of comparable products, quoted in domestic currency, and adjusted up or down 
to reflect quality differences. This price setting process isolated domestic firms from the influence of relative domestic and international price and exchange rate changes. For imports without domestic equivalents, which accounted for 20 percent of all imports, domestic prices were based on the cost of imports converted to domestic currency at the official exchange rate. Since this exchange rate was overvalued, the imports were in effect subsidized. The consequences of these policies were lagging exports, low growth in trade volume, and a distorted commodity composition of foreign trade, which did not correspond to China's comparative advantage in the production of labor intensive goods.

The EP system helped remedy these problems. Initially the system provided various incentives for both the processing of raw materials for export and the assembly of imported parts and components to produce finished goods for export (known as processing and assembling or processing with supplied materials). As tariffs became very important in the 1980s, these incentives were expanded in 1987 to allow for duty-free imports of all raw materials and intermediate inputs used in the production of exports. These duty exemptions contributed strongly to China's actual collection rate being only one-sixth of its weighted average tariff rate (World Bank 1994) ${ }^{1}$ and led to a tremendous increase in processed exports utilizing imported materials in China. In the span of just three years, processed exports produced with inputs purchased from abroad almost tripled, increasing from US\$140 million in 1988 to US\$324 million in 1991, while total exports rose by 50 percent (World Bank 1994). In 2000, EP trade in China accounted for 50 percent of total trade, with EP accounting for 55 percent of total exports. The share of concessional imports in total imports rose from one-third to around one-half between 1988 and 1991 and has remained around this level since then.

\footnotetext{
${ }^{1}$ Concessional imports cannot alone explain the low collection rates. A collection rate of 5.6 percent represents only 17.5 percent of the trade weighted average tariff of 32 percent for 1991 (World Bank 1994). Other imports by the government such as imports used for priority projects were also exempt. It is also possible that there were other leakages in the revenue collection system.
} 
Duty exemptions increase the economy's competitiveness and efficiency. In the absence of duty drawbacks the protection of import competing firms is in general positive, while that of export competing firms is negative (Figure 1). ${ }^{2}$ This is because export competing firms face world prices while domestic competing firms are protected by tariffs on final goods. Duty drawbacks reduce the Effective Rates of Protection (ERPs) for export competing firms to $0,{ }^{3}$ which allows export producers to operate at world prices, and halve the standard deviation in ERPs, which in turn increases the efficiency of the economy.

Despite the presence and vast importance of duty drawbacks in China and other developing countries, these "new trade liberalization" instruments have been given relatively little attention both in trade negotiations and in empirical multilateral trade liberalization studies. A paper by Panagariya (1992) provides a systematic analysis of the effects of input tariffs and duty drawbacks on welfare, but standard global trade models (Hertel 1997) have abstracted from the presence of concessional imports, while trade liberalization studies using these models have at best offered only partial solutions to the problem (Bach, Martin and Stevens 1997). Recently, the topic of concessional import arrangements has been considered in papers by Gruen (1999), Cadot, de Melo and Olarreaga (2003), and Fan and Li (2000). Gruen (1999) illustrates the similarities and differences between traditional and "new trade liberalization" instruments such as export processing zones (EPZs) and duty drawback schemes, and concludes that in theory both can bring about complete free trade. Cadot et al. (2000) consider the political economy implications of duty-drawback schemes for the incentives of export industries to lobby against upstream tariffs on imported intermediates.

\footnotetext{
${ }^{2}$ Figure 1 illustrates these points by showing effective rates of protection (ERP) in China. These ERP are based on protection data in 1995 as presented in version 4 GTAP and are computed for import and export competing firms separately to emphasize differences in protection depending on the orientation of the firms.

${ }^{3}$ The ERPs for export processing firms with duty exemptions are close but not exactly zero because the domestic components of value added still have import duties embedded in them.
} 
Acknowledging the importance of duty drawbacks for China's export processing system, Fan and Li (2000) implement duty exemptions in a one-region recursive dynamic model of China.

This paper presents an empirical multi-region general equilibrium model in which the effects of policy reform are differentiated based on the trade orientation of the firms. The resulting model could be used to analyze trade liberalization in the presence of duty drawbacks, assess whether countries should introduce or abolish these types of arrangements, and evaluate the economy-wide impact of improved administration of the duty drawback system. The method is similar to that of Fan and Li (2000), yet it differs in that it allows implementation of partial and/or full duty drawbacks in any number of regions in an empirical multi-region general equilibrium model. The model discussed here is designed so that in the absence of duty exemptions, its solution coincides with the solution of GTAP (Hertel 1997), a widely used applied general equilbrium model for trade policy analysis. This feature is attractive as it permits evaluation of various unilateral trade reforms, regional and multilateral trade agreements under different assumptions for duty drawbacks in different regions within the same modeling framework.

The importance of duty exemptions for the analysis of China's WTO accession is shown by conducting two experiments - one with GTAP, which ignores duty exemptions, and another one with the model featuring duty drawbacks. The comparison of the results from the two experiments suggests that findings of studies that have looked at China's entry to the WTO without taking into account duty exemptions (Martin et al. 1999; Bach et al., 1996; Walmsley and Hertel, 2001) may be seriously biased. Failure to take into account duty exemptions on imports for production of exports in China will overstate the impact of China's entry to the WTO on the country's trade flows and welfare by 40 percent and 15 percent, respectively. The magnitude of the bias depends on the level of pre-intervention tariffs and the size of tariff cuts - 
the larger the initial distortions and tariff reductions, the larger the bias when duty drawbacks are ignored. The bias in the estimates of China's real GDP, trade flows and welfare changes due to WTO accession increases more than three times when China's pre-intervention tariffs are raised from their 1997 levels to the much higher 1995 levels. These results suggest that trade liberalization studies focusing on economies, in which protection is high, import concessions play an important role and planned tariff cuts are deep, must treat duty drawbacks explicitly in order to avoid serious errors in their estimates of sectoral output, trade flows and welfare changes.

The paper is structured as follows. Section 2 introduces the general equilibrium model with duty drawbacks. Section 3 discusses data and parameters for this study. Section 4 illustrates the importance of representing duty exemptions explicitly with an example of the impact of China's WTO accession. Section 5 concludes with a summary of the findings.

\section{The model}

We consider a world with $R$ regions each endowed with $F$ types of endowments and producing $G$ types of goods. There is a one-to-one correspondence between goods and industries. In each industry there are two types of competitive firms - export-oriented and domestic-oriented. All export-oriented firms are identical and form the export-oriented sub-sector of an industry. Similarly, domestic-oriented firms are identical and form the domestic-oriented sub-sector of an industry. Both types of firms produce the same commodity using the same technology and are identical in all respects except one - the export-oriented firms produce exclusively for export markets using imported intermediates that are either exempt from duties or eligible for refunds on the import tax paid, while the domestic-oriented firms produce no exports and supply 
exclusively the domestic market. Production for domestic and export markets is therefore completely decoupled.

The choice to fully separate domestic and export production simplifies considerably the representation of duty drawbacks in a large empirical multi-region model. It is preferable to representations based on a single sector producing differentiated products for domestic and export markets because it allows the two sectors to use quite different input mixes, and particularly for the export-oriented activities to use much more import-intensive means of production. It is also a fairly accurate depiction of the trade regime in countries where duty drawbacks are used as export promotion instruments while protection on the rest of the economy is fairly high. ${ }^{4}$

One of the $\mathrm{G}$ industries produces a nontradable investment good, which could be installed in a domestic or an export-oriented firm. The model captures the fact that a portion of imported intermediate capital goods are duty exempt. This is an important feature since tax concessions for imported capital goods are popular in many developing countries. For example, capital goods brought into China for export processing by foreign-invested enterprises have been exempt from import duties during most of the 1990s.

Export producers in region $r$ supply $X_{j r}$ of good $j$ to export markets, ${ }^{5}$ while domesticoriented producers supply $D_{j r}$ of good $j$ to local markets. The intermediate input demand for input $i$ in industry $j$ of region $r, I_{i j r}^{\Omega}$, where superscript $\Omega \in\{D, X\}$ indicates the type of subsector ( $D$ stands for the domestic-oriented one, $X$ stands for the export-oriented one), is

\footnotetext{
${ }^{4}$ In a deterministic world, a producer of exports will always take advantage of duty exemptions or duty rebates unless the administrative costs of the export processing arrangements are excessive.

${ }^{5}$ The sector producing investment goods is an exception since its exports are zero.
} 
proportional to the level of activity in sector $j$ and determined by fixed intermediate input coefficients $a_{i j r}$ :

$$
I_{i j r}^{\Omega}=a_{i j r} \Omega_{j r}
$$

where $i, j \in\{1, \ldots, G\}, r \in\{1, \ldots, R\}$.

Firms purchase both foreign and domestic intermediates, which are imperfect substitutes in a constant-elasticity-of-substitution (CES) composite function (Armington 1969). Producers for the domestic and export markets minimize unit intermediate input costs subject to input prices and the CES function that relates the level of activity to intermediate inputs: ${ }^{6}$

$$
\begin{aligned}
& I_{i j r}^{D \Omega}=I_{i j r}^{\Omega} a_{i j r}^{I^{D} \Omega}\left(p_{i r}^{D}, p_{i r}^{M \Omega}\right), \\
& I_{i j r}^{M \Omega}=I_{i j r}^{\Omega} a_{i j r}^{I^{M} \Omega}\left(p_{i r}^{D}, p_{i r}^{M \Omega}\right),
\end{aligned}
$$

where $i, j \in\{1, \ldots, G\}, r \in\{1, \ldots, R\} ; I_{i j r}^{D \Omega}$ is the demand of sub-sector $\Omega \in\{D, X\}$ of industry $j$ for domestic intermediate $i ;^{7} I_{i j r}^{M \Omega}$ is the demand of sub-sector $\Omega \in\{D, X\}$ of industry $j$ for imported intermediate good $i ; p_{i r}^{D}$ is the domestic price of good $i$ in region $r, p_{i r}^{M \Omega}$ is the import price of good $i$ used for final consumption or as intermediate input by sub-sector $\Omega \in\{D, X\}$ in region $r$. Duty drawbacks for imported materials used in the production of exports imply that the intensity of imported intermediate use by the export sector is higher than the intensity of imported intermediate use by the sector producing for the local market.

Zero profit for the choice of composite inputs imply that:

$$
p_{i j r}^{I \Omega}=c_{j}^{I \Omega}\left(p_{i r}^{D}, p_{i r}^{M \Omega}\right)
$$

\footnotetext{
${ }^{6}$ Functional forms are represented explicitly, but unit demand and supply functions are shown in reduced form, i.e. $a\left(\right.$.), where superscripts $I^{D}$ and $I^{M}$ stand for intermediate use of domestic and imported goods, respectively.

${ }^{7}$ The first superscript determines whether the intermediate inputs are domestic or imported. The second superscript defines whether they are used by the domestic-oriented sub-sector or the export-oriented sub-sector.
} 
where $i, j \in\{1, \ldots, G\}, r \in\{1, \ldots, R\} ; c_{j}{ }^{\Omega}($.$) is the unit cost function defined by the CES$ aggregates of domestic and imported interemediate inputs for sub-sector $\Omega \in\{D, X\}$ of industry $j$; and $p_{i j r}^{I \Omega}$ is the composite demand price of good $i$ for intermediate use by subsector $\Omega \in\{D, X\}$ of industry $j$ in region $r$.

Producers minimize unit factor costs given the vector of factor prices $p_{f r}^{F}$ and relevant taxes $t_{f r}^{F}$, and a CES function that relates the level of output to the factor inputs. Linear homogeneity of the production function implies that factor demands of sub-sector $\Omega \in\{D, X\}$ in industry $j$ of region $r\left(F \frac{\Omega}{f j r}\right)$ can be written as:

$$
F_{f j r}^{\Omega}=\Omega_{j r} a_{f j r}^{F \Omega}\left(p_{f r}^{F}, t_{f r}^{F}\right)
$$

where superscript $\mathrm{F}$ stands for factor use, $f \in\{1, \ldots, F\}, j \in\{1, \ldots, G\}, r \in\{1, \ldots, R\}$.

Imports of good $i$ in region $r$ for the production of goods sold domestically and for exports are CES composites of imports from various sources $s, M_{i s r}^{\Omega},{ }^{8}$ where $\Omega \in\{D, X\}$, respectively. Consequently, bilateral imports, determined by cost-minimizing choice, given the fob export prices $p_{i r}^{X}$, the export tax rate $t_{i r s}^{X}$, the import tariff rate $t_{i r s}^{M}$ and transport costs $\tau_{i r s}$, are given by:

$$
\begin{aligned}
& M_{i s r}^{X}=\left(\sum_{j} I_{i j r}^{M X}\right) \cdot a_{i s r}^{M X}\left(p_{i s}^{X}, t_{i s r}^{X}, t_{i s r}^{M}, \tau_{i s r}\right), \\
& M_{i s r}^{D}=\left(C_{i r}^{M}+\sum_{j} I_{i j r}^{M D}\right) a_{i s r}^{M D}\left(p_{i s}^{X}, t_{i s r}^{X}, t_{i s r}^{M}, \tau_{i s r}\right),
\end{aligned}
$$

where $C_{i r}^{M}$ is consumption of imported good $i$ in region $r, i, j \in\{1, \ldots, G\} ; s, r \in\{1, \ldots, R\}$.

\footnotetext{
${ }^{8}$ Subscript $s$ stands for 'source' region, while subscript $r$ stands for 'destination' region.
} 
Output of the domestic-oriented sub-sector $i$ in region $r\left(D_{i r}\right)$ meets demand for domestic intermediate products, and final demand for good $i$ in region $r$ :

$$
D_{i r}=\sum_{\Omega} \sum_{j}\left(I_{i j r}^{D \Omega}\right)+C_{i r}^{D}
$$

where $\Omega \in\{D, X\}, i, j \in\{1, \ldots, G\}, r \in\{1, \ldots, R\}$. Output of the export sector meets import demand of all trading partners:

$$
X_{i r}=\sum_{\Omega} \sum_{s}\left(M_{\text {irs }}^{\Omega}\right)
$$

where $\Omega \in\{D, X\}, i \in\{1, \ldots, G\} ; r, s \in\{1, \ldots, R\}$.

Primary factor supply is exogenous and equals primary factor demand:

$$
F_{f r}=\sum_{\Omega} \sum_{j} F_{f j r}^{\Omega}
$$

where $\Omega \in\{D, X\}, f \in\{1, \ldots, F\} ; j \in\{1, \ldots, G\} ; r \in\{1, \ldots, R\}$.

Competitive producers in both the export-oriented and domestic-oriented sub-sectors earn zero profit in equilibrium:

$$
p_{i r}^{\Omega}=\sum_{f} a_{f i r}^{F \Omega} p_{f r}^{F}\left(1+t_{f i r}^{F}\right)+\sum_{j} a_{j i r} p_{j i r}^{I \Omega}\left(1+t_{j i r}^{I \Omega}\right),
$$

where $\Omega \in\{D, X\}, i, j \in\{1, \ldots, G\}, f \in\{1, \ldots, F\}, r \in\{1, \ldots, R\} ; t_{j i r}^{I \Omega}$ is a tax on intermediate inputs. In equilibrium, the domestic cif price equals the fob price gross of export tax, the applicable tariff, and transport costs:

$$
\begin{aligned}
& p_{i r}^{M D}=\sum_{s} a_{i s r}^{M D}\left[p_{i s}^{X}\left(1+t_{i s r}^{X}\right)\right]\left(1+t_{i s r}^{M}\right)\left(1+\tau_{i s r}\right), \\
& p_{i r}^{M X}=\sum_{s} a_{i s r}^{M X}\left[p_{i s}^{X}\left(1+t_{i s r}^{X}\right)\right]\left(1+\phi t_{i s r}^{M}\right)\left(1+\tau_{i s r}\right),
\end{aligned}
$$


where $i \in\{1, \ldots, G\}, s, r \in\{1, \ldots, R\}, \phi$ is a parameter between 0 and 1 that determines the extent of liberalization of the export processing sector.

If $\phi$ is zero, export producers get duty exemptions or full rebates of their import duty. If $0<\phi<1$, export producers get partial refunds. If $\phi=1$ import taxes are the same for the export and domestic sub-sectors. Equations (4), (11) through (13) show that duty drawbacks improve the exporters' competitiveness as their costs either do not reflect import duties or reflect reduced import taxes due to partial duty rebates.

Equations (1) through (13) describe the changes needed in order to implement duty drawbacks in a standard multi-region applied general equilibrium model. For comparison purposes all other equations of the model come from the GTAP model (Hertel 1997) and for the sake of brevity are not shown here. ${ }^{9}$ The model is implemented in GEMPACK (Harrison and Pearson 1996). When imported intermediate inputs used by exporting firms are taxed at the same rates as those used by firms selling locally, tariff cuts on imported intermediate inputs are the same regardless of their use, and the input composition of the export-oriented sub-sector is identical to the input composition of the domestic-oriented sub-sector, the solution with this model is identical to the solution with GTAP; otherwise the solutions differ.

\footnotetext{
${ }^{9}$ A brief summary of these features follows. Consumers and the government receive income from payments for primary factor services and tax revenue, respectively, and save a fixed share of their income. Consumers maximize a constant-difference-elasticity (CDE) demand system, while public consumption is governed by a Cobb-Douglas utility function. As in the case of intermediate inputs, both private and government final demands are a CES composite of domestic and imported products. The consumer price level is the numeraire, and aggregate investment is such that the trade balance is a fixed share of income.
} 


\section{The data}

The experiments assessing the importance of duty drawbacks for the analysis of China's WTO accession employ version 5 GTAP database (Dimaranan and McDougall 2002), aggregated to 20 regions (Table 1 ) and 25 sectors (Table 2). Some tax rates in China were changed using the approach in Malcolm (1998) ${ }^{10}$ in order to reflect the following additional information: export subsidies for feedgrains and plant-based fibers at $32 \%$ and $10 \%$, respectively, and nominal protection rates for agricultural commodities as suggested by Huang et al. (2002) (Table 4, column 2); the tax rate on unskilled nonagricultural labor at $34 \%$ as in Ianchovichina and Martin (2003) and based on information in Shi Xinzheng (2002), export taxes on textiles and apparel exports to the United States at $11 \%$ and $15 \%$, respectively, and to the European Union at $12 \%$ and $15 \%$, respectively. ${ }^{11}$

Since the GTAP data do not distinguish inputs based on whether they are used for export or domestic production, it was necessary to split the factor and intermediate input usage of each sector and region into domestic-oriented and export-oriented firms' usage. For China, ideally, we would like to use information on duty exempt imports by product and sector use and factor usage by sector and sub-sector (for export or domestic use). This information is typically difficult to obtain. China Customs, for instance, keeps track of imported intermediate input use by product, but not by sector. Initially the data on imported intermediate inputs in GTAP were split using information on duty-exempt imports by product in China at the HS2 level from China Customs. However, resulting data could not be employed in the analysis because they did not contain information on duty-exempt imports by sector use and the commodity classes at

\footnotetext{
${ }^{10}$ This approach ensures that the adjustment are made while preserving the share information in the data base.

11 The export tax equivalents were estimated and used by Ianchovichina and Martin (2003).
} 
the level of aggregation for China Customs data often overlapped two or more GTAP categories. Moreover, the reported imports of duty-free intermediate inputs for export production from China Customs exceeded the total intermediate use obtained from China's input-output tables in the GTAP data.

Several explanations come to mind, including data error, strong substitution toward the duty-free intermediates in the export processing sectors, and fraudulent misclassification of intermediates not destined for export processing. ${ }^{12}$ As a result of these problems, the data set for the new model produced with this external information seriously distorted the original input-output and tax information in the GTAP data base.

In order to get around this problem and the lack of data, the domestic and export subsectors were initially created by dividing each sector's intermediate and factor input use in proportion to the domestic and export shares of output in a region. ${ }^{13}$ Since data sources suggest that nearly all imports purchased for production of capital goods in China were subject to duty exemptions, ${ }^{14}$ we assume that the capital goods sector in China uses only duty exempt imported capital intensive manufactures. To preserve the tax information in the GTAP data, factor endowment, imported and domestic intermediate input use of the export and domestic-oriented sub-sectors at market prices are computed in the same way as the corresponding input use at

\footnotetext{
${ }^{12}$ There is evidence that smuggling and various violations of the export processing regulations are common forms of fraud and account for approximately half of all trade related fraud. Estimates, based on data gathered by Naugton (2000) during interviews with Chinese officials in 1999, suggest that in the late nineties the value of all trade related fraud in a year was well over US\$ 10 billion. Companies might under-invoice imports in order to use part of the undeclared materials to produce for the domestic market. Companies might over-invoice imports when they intend to either over-invoice exports, which is most common, or over-report the unit consumption of materials and use the over-invoiced portion to produce for the domestic market (Ianchovichina 2001).

13 This method ensures that, for regions other than China, the treatments in GTAP and the new model are identical when tariffs and tariff reductions for imported intermediate inputs for export and domestic use are the same.

${ }^{14}$ According to GTAP 11 percent of total imports are used in the production of capital goods and according to the China Council (2001) 13 percent of imports are duty free imports used in the production of investment goods.
} 
agents' prices. Imports of commodity $i$ into region $s$ used for production of exports and for domestic sales by source $r$ were computed from the data on bilateral imports by commodity in GTAP as follows :

$$
\begin{aligned}
& M_{i r s}^{X}=\gamma_{i s} M_{i r s}, \\
& M_{i r s}^{D}=\left(1-\gamma_{i s}\right) M_{i r s},
\end{aligned}
$$

where $i \in\{1, \ldots, G\}, r, s \in\{1, \ldots, R\}, M_{\text {irs }}$ are bilateral imports of good $i$ from region $r$ into

region $s$ in the GTAP database, and $\gamma_{i s}=\frac{\sum_{j} I_{i j s}^{M X}}{\sum_{r} M_{i r s}}$, where $j \in\{1, \ldots, G\}$.

This approach ensures that the sum of imported intermediates $i$ by exporters in region $\mathrm{s}$ equals the sum of imported intermediates $i$ from all regions $r$ into region s. Similarly, the sum of imported intermediates $i$ by domestic-oriented producers in region $\mathrm{s}$ and imports of good $\mathrm{i}$ for final consumption equals the sum of imports of good $i$ used for domestic use from all regions $r$ into region s.

The next step was to eliminate tariffs on intermediate manufactured imports used in the production of exports in the newly created database using the approach in Malcolm (1998), modified so that all elasticities of subsitution except those between domestic and intermediate goods in China were set to 1 . The elasticity of substitution between domestic and intermediate goods in China was set at twice its value in the GTAP database. This approach increased the import-intensity of the exporting sectors as tariffs on imports used for export processing were eliminated. It raised the share of imports used by the export activities in China to 30 percent (Table 7), while preserving key aggregate statistics of the GTAP database (Table 1; columns 3 
and 4 of Table 2; last row of Table 3; Table 7). China's sectoral shares in world output, exports and imports were changed somewhat, but in all cases these changes were negligible (Table 3).

In the new data, import taxes on imports for domestic use were preserved and equal to the import tax rates on imports in version 5 GTAP database, while taxes on manufactured imports for the production of exports were set at zero (Table 4). Import taxes on farm products were left unchanged since evidence suggested limited use of duty exemptions for farm imports. ${ }^{15}$ Protection on cross-border trade in services also do not differ based on the trade orientation of the firms.

All parameters for the two experiments come from version 5 GTAP data (Dimaranan and McDougall 2002). These include the Allen partial elasticities of substitution that describe the substitutability between domestic and imported intermediates, the substitutability between imported intermediates from different sources, and the substitutability between primary factors. Furthermore, the Allen partial elasticities of substitution in the domestic-oriented sub-sector of a sector are the same as those in the export-oriented sub-sectors of the economy. This reflects the assumption that all firms are identical and facilitates the comparison between GTAP and the model with duty drawbacks. ${ }^{16}$

\section{Analysis of China's WTO Accession}

The importance of duty drawbacks for the analysis of policy reform is illustrated by evaluating the impact of China's WTO accession first using the GTAP model, and then the model with

\footnotetext{
${ }^{15}$ A number of farm products are still subject to state trading (World Trade Organization 2001). More recently, Huang et al. (2002) show that a number of products faced negative protection rates (Table 4).

${ }^{16}$ The assumption ensures that in the absence of duty exemptions and conditional on the assumptions listed above, the solution to the model with duty drawbacks coincides with the solution to the GTAP model.
} 
duty drawbacks in section 2 . The comparison of the results from the two models suggests that results of studies which have abstracted from China's duty exemptions when analyzing China's entry to the WTO (Martin et al. 1999; Bach et al. 1996; Walmsley and Hertel 2001) may be seriously biased. The presence of duty exemptions is an important determinant of the outcome of trade liberalization. With duty exemptions on imported inputs for export processing, the liberalization in China affects only intermediate imports for domestic use and imports for final consumption. Therefore, its impact on output, trade flows and welfare is smaller than the one, captured with GTAP which abstracts from duty exemptions. The impact is significantly smaller for those industries that rely heavily on imported intermediates.

\subsection{Experimental design}

The simulation design for the pair of experiments follows closely Ianchovichina and Martin (2003), but for simplicity and comparison purposes the changes associated with accession are evaluated in a comparative static context. Both experiments are designed to reflect the impact of WTO accession which involves (a) liberalization from 1997 tariffs to post accession tariff rates (2007) (Table 4), ${ }^{17}$ (b) the elimination of quotas on China's textile and clothing exports to the US and EU markets; ${ }^{18}$ (c) the removal of agricultural export subsidies for feedgrains and plant-based fibers (cotton) in China (Huang et al. 2002); (d) the liberalization of China's crossborder trade in services; and (e) the restructuring of the Chinese automobile sector ${ }^{19}$ (Francois and Spinanger 2002). The two experiments differ only in that tariff cuts in GTAP are the same

\footnotetext{
17 China's own protection is reduced to the lesser of the tariff binding or the 2001 applied rate. The experiment features also tariff cuts as part of Chinese Taipe's accession to the WTO.

${ }^{18}$ Quotas on textile and apparel exports have been represented in the analysis as if they were an export tax.

19 The restructuring of the automobile sector is represented as a 20 percent productivity gain to car assembly operations.
} 
for all imports regardless of their use, whereas tariff cuts on manufactured imports used by the export processing sector are zero in the model with duty exemptions (Table 4).

The macroeconomic closure assumes full employment, perfect mobility of skilled and unskilled workers between sectors, and fixed trade balance as a share of GDP in China and Chinese Taipei. ${ }^{20}$ Since accession to the WTO involves a long run change in the stance of trade policy the elasticity of substitution between imported goods from different sources and between composite imported and domestic goods in the GTAP data base were doubled.

\subsection{Results}

China's output, export, and import changes due to WTO accession, obtained with GTAP and the model with duty drawbacks, are shown in Table 5. Columns 4, 7 and 10 of Table 5 show the bias introduced in the results when duty exemptions are not considered in the analysis. Both models lead to very similar estimates of world output change. The increase in China's real GDP due to the country's accession to the WTO is small reflecting the fact that both models do not include the linkage between trade reform and productivity growth.

At the sectoral output level, however, China's WTO accession boosts production in a number of sectors, including apparel, textiles, cotton and automobiles. Automobile manufacturing gets a boost as a result of the assumed increase in productivity of assembly-type operations and the tariff reductions on imported intermediate inputs such as auto parts. The expansion of the apparel industry is associated with the lifting of the burdens imposed by the MFA on China's exports and domestic protection on the cost structure of the industry. This expansion in apparel in turn boosts China's textiles and cotton sectors.

\footnotetext{
${ }^{20}$ While the trade balance can be expected to vary, particularly if there is a substantial change in foreign investment levels, there is no link between the change in foreign investment and the chage in income in GTAP and the new model.
} 
The results from the two models differ quantitatively. With GTAP accession to the WTO leads to an increase in China's apparel output by 96 percent (column 5, Table 5), while with the model with duty drawbacks this increase is 81 percent. This implies that with GTAP the increase in China's output of apparel is approximately 20 percent higher than the one predicted with the duty drawbacks model, which captures the expansion of apparel as a result of export quota removal while taking into account duty exemptions on imported inputs used in the production of apparel exports. These exemptions have essentially opened up the export-oriented apparel sector as they affected two-thirds of intermediate inputs in the apparel industry, and imply that the output increases are attributed mainly to the lifting of the burdens imposed by the MFA on China's apparel exports.

In some cases the results with the two models differ not only quantitatively, but also qualitatively. Given the large importance of export processing arrangements and duty exemptions in the electronics sector (Table 2) and the significant tariff cuts on electronic products (Table 4), the model with duty drawbacks suggests a small contraction in the output of electronics due to China's WTO accession. By contrast GTAP misses the effect of duty exemptions on output and estimates a small export-driven increase in electronics output (Table $5)$.

The impact of WTO accession on China's share in world trade is much stronger than the one on China's share in world output (Table 5). According to GTAP, China's exports and imports rise by 32 percent due to accession..$^{21}$ The model with duty drawbacks also estimates a strong, however, more modest increase in China's exports and imports (23 percent) because it

\footnotetext{
21 The similar increase in imports and exports reflects the assumption that China's trade balance is a fixed share of GDP.
} 
allows for the partial liberalization implicit in the exemption scheme on intermediate inputs used in the production of exports.

A comparison of the sectoral trade flow changes suggests that for some sectors - for example, electronics - the bias introduced by ignoring duty exemptions in China could be significant - a difference of 26 percent in the estimated percentage changes with the two models or an increase in exports with the duty drawbacks model that is 90 percent smaller than the one with GTAP. In the case of apparel, there is a 13 percent difference in the estimated percentage changes with the two models or an increase in exports with the new model which is 45 percent smaller than the one with GTAP. For these sectors the export expansion with the model with duty drawbacks is strong, but much less so than with GTAP because duty exemptions have already removed much of the burden of protection on the export sector in China and any benefits of tariff cuts have a smaller, indirect impact. Failure to take into account duty exemptions on imported inputs used in the production of exports also leads to serious bias in the estimation of import changes for a number of products among which textiles (18 percent), apparel (16 percent), automobiles (15 percent), light manufactures (16 percent) and other manufactures (11 percent) (Table 5).

Table 6 shows regional welfare changes due to China's entry to the WTO computed with GTAP (column 2) and the model with duty drawbacks (column 3). While qualitatively the changes in regional welfare are broadly the same, quantitatively the results differ substantially. Indeed, GTAP overestimates China's welfare gain by almost 15 percent. This is due to an upward bias in the allocative efficiency gain most of which is due to gains in textiles (46 percent), apparel (23 percent), electronics (13 percent) and other manufactures (11 percent) (last column of Table 6). The presence of a well functioning duty exemption scheme implies that to a large extent China's liberalization has already been captured prior to accession, and 
therefore the allocative efficiency gains associated with an improved allocation of resources across sectors due to WTO accession will be smaller than suggested by GTAP.

For other regions, this implies that the change in their welfare will be mainly due to the removal of restrictions on Chinese exports and not so much to removal of China's import tariffs. This, in turn, translates into smaller gains for developed countries and smaller loses for developing countries when duty exemptions are modeled explicitly. As a result the global welfare gain with GTAP is approximately 30 percent larger than the gain estimated with the model with duty drawbacks.

\subsection{Size of the bias and initial protection}

The degree of bias in estimating the changes due to trade reform with GTAP depends on the magnitude of the initial tariffs and tariff cuts - the larger the initial distortion and tariff reduction, the larger the bias when duty exemptions are ignored. The increase in the bias results from the fact that GTAP captures additional cost saving and efficiency gains associated with the rise in initial distortions and tariff cuts since it does not take into account duty exemptions for export processing.

In China weighted average tariffs in 1997 were much lower than tariffs in 1995 (Table 8). Consequently, the bias in the estimated impact of tariff reductions from 1995 to post accession tariff levels with GTAP would be much larger than the bias in the estimated impact of tariff cuts from 1997 to post accession tariffs. Tables 9 and 10 show changes in output, trade, and welfare due to WTO accession, which involves liberalization from 1995 tariff levels. The experimental design is identical to the one presented in section 4.1 except for the tariff cuts, which are larger than the ones applied earlier since tariffs in 1995 were higher than tariffs

in 1997 (Table 8). Results in Tables 9 and 10 suggest that the bias in GTAP's estimates of 
China's real GDP, trade flows and welfare changes due to WTO accession increases more than 3 times when China's pre-intervention tariffs are raised from their 1997 levels to the much higher levels in 1995. For example, GTAP overestimates China's welfare gain due to WTO accession from 1995 tariffs by 48 percent (Table 10), whereas the bias in the estimated gain due to WTO accession from 1997 tariffs is just 15 percent (Table 6). This increase in the bias in the estimated welfare gain is due to the fact that in the face of larger initial distortion and tariff cuts the GTAP model estimates a much larger (4 times) second best efficiency gain as it ignores the fact that the export sector benefits from duty exemptions on imported intermediate inputs.

The bias in the sectoral results is also worse in the case of liberalization from 1995 tariffs compared to liberalization from 1997 tariffs. It is largest for sectors in which 1995 tariffs are much larger than 1997 tariffs. The bias doubles in the case of electronics and triples in the case of apparel. It is 46 times larger in the case of automobile output and 15 times larger in the case of automobile exports and imports (Tables 5 and 9).

\section{Conclusions}

Concessional import rights, such as duty exemptions, which override existing protection, have been an important element of the process of gradual trade liberalization that has boosted growth in China and other countries. Despite their vast importance, duty drawbacks have been given relatively little attention in trade negotiations and multilateral trade liberalization studies. Standard global trade models have largely abstracted from the presence of concessional imports, while trade liberalization studies using these models have at best only acknowledged their importance and have not offered an in-depth solution to the problem.

This paper presents a model with duty drawbacks in which the effects of policy reform are differentiated based on the trade orientation of the firms. The model treats explicitly both 
duty drawbacks on imported intermediate inputs and investment goods used for the production of exports. The paper evaluates the importance of duty exemptions in China by assessing the impact of China's WTO accession, which involves liberalization from 1997 to post-accession tariffs among a number of other liberalization measures, on the country's output, trade and welfare. The analysis, which uses first GTAP and then the model with duty drawbacks, suggests that the absolute magnitudes of changes in sectoral output and trade flows due to accession are larger, sometimes substantially, with GTAP compared to those with the duty drawbacks model. The analysis shows that failure to account for duty exemptions in the case of China's recent WTO accession will overstate the increase in China's aggregate trade flows by 40 percent and China's welfare by 15 percent. This reflects the fact that duty exemptions have reduced substantially border protection in China prior to WTO accession. Consequently, any boost to trade and efficiency gains associated with an improved allocation of resources across sectors due to WTO accession will be smaller with the proposed model than with GTAP.

The magnitude of the bias in estimating the changes due to trade reform with GTAP depends on the level of initial tariffs and the size of the tariff cuts - the larger the initial distortion and tariff reductions, the larger the bias when duty exemptions are ignored. The bias in GTAP's estimates of China's real GDP, trade flows and welfare changes due to WTO accession increases by more than three times when China's pre-intervention tariffs are raised from their 1997 levels to the much higher 1995 levels. These results suggest that trade liberalization studies focusing on economies in which protection is high, import concessions play an important role, and planned tariff cuts are deep must always treat duty drawbacks explicitly in order to avoid serious errors in their estimates of sectoral, trade flow, and welfare changes. 


\section{References}

Armington, P. 1969. 'A theory of Demand for Products Distinguished by Place of Production', IMF Staff Papers, 16:159-178.

Bach, C., Martin, W. and Stevens, J. 1996. 'China and the WTO: tariff offers, exemptions and welfare implications' Weltwirtschaftliches Archiv 132(3):409-31.

Cadot, O., de Melo, J. and Olarreaga, M. 2003. 'The Protectionist Bias of Duty Drawbakcs: Evidence from Mercosur', Journal of International Economics, 59(1), pp. 161-82.

China Council. 2001. China Business Guide, China Council for the Promotion of International Trade / China Chamber of International Commerce (eds), Beijing, China.

Dimaranan, B. and R. McDougall 2002.Global Trade, Assistance, and Production: The GTAP 5 Data Base, Center for Global Trade Analysis, Purdue University.

Fan, Zhai and Li, S. 2000. 'The Implications of Accession to WTO on China's Economy', paper presented at the Third Annual Conference on Global Economic Analysis, Melbourne, Australia, June 27-30, 2000.

Francois, J. and Spinanger, D. 2002. 'The Motor Vehicle Sector in China and WTO Accession,' paper presented at the Seminar on WTO Accession, Policy Reform and Poverty Reduction in China, World Bank, Beijing, June 28-29, 2002.

Gruen, N. 1999. “Towards a More General Approach to Trade Liberalization" The Economic Record 75:385-396.

Harrison, J. and Pearson, K. 1996. 'Computing Solutions for Large General Equilibrium Models Using GEMPACK', Computational Economics 9(2), pp. 83-127.

Hertel, T. 1997. Global Trade Analysis: Modeling and Applications, Cambridge University Press, Cambridge.

Huang, J., Rozelle, S. and Min, C. 2002. 'The Nature of Distortions to Agricultural Incentives in China and Implications of WTO Accession', paper prepared for the conference WTO Accession, Policy Reform and Poverty Reduction, Beijing, June 26-28, 2002.

Ianchovichina, E. 2001. 'China's WTO Accession and Export Processing Trade', mimeo, World Bank.

Ianchovichina, E. and Martin, W. 2001. 'Trade Liberalization in China's Accession to WTO', Journal of Economic Integration 16(4), pp. 421-445.

Ianchovichina, E. and Martin, W. 2003. 'Economic Impacts of China's Accession to the World Trade Oragnization', Policy Research Working Paper No. 3053, The World Bank, Poverty Reduction and Economic Management Network, Economic Policy Division and Development Research Group, Trade. 
Lardy, N., 2002. 'Trade Reforms Prior to Entering the WTO', Chapter 2 in Lardy, ed. Integrating China in the Global Economy, Washington, D.C.: Brookings Institution Press.

Malcolm, G. 1998. “Adjusting Tax Rates in the GTAP Database” GTAP Technical Paper No. 12, Center for Global Trade Analysis, Purdue University (www.gtap.org).

Martin, W., Dimaranan, B. and Hertel, T. 1999. "Trade Policy, Structural Change and China's Trade Growth" Paper presented to the Conference on Policy Reform in China, Center for Research on Economic Development and Policy Reform, Stanford University, November 18-20.

McDougall, R., Elbehri, A. and Truong, T. 1998. Global Trade, Assistance and Protection: The GTAP 4 Data Base. Center for Global Trade Analysis, Purdue University.

Naughton, B., 2000. "China's Trade Regime on the Eve of WTO Accession:

Achievements, Limitations, and Implications for the US," Forthcoming in Ted Galen Carpenter and James Dorn, eds. China's Future: Constructive Partner or Emerging Threat? Washington, D.C.: Cato Institute, July 2000.

Panagaryia, A. 1992. 'Input Tariffs, Duty Drawbacks, and Tariff Reforms," Journal of International Economics 32(1-2), pp. 131-147.

Shi, Xinzheng (2002), 'Empirical Research on Urban-Rural Income Differentials: A Case of China,' mimeo, Peking University.

Walmsley, T. L. and Hertel, T.W. 2001. China's Accession to the WTO: Timing is Everything, World Economy 24(8), pp. 1019-49.

World Bank 1994. China: Foreign Trade Reform. Washington DC: World Bank.

World Trade Organization 1994. The Results of the Uruguay Round of Multilateral Trade Negotiations. Geneva: World Trade Organization.

World Trade Organization 2001. 'Draft Report of the Working Party on the Accession of China,' (www.insidetrade.com). 
Figure 1. China's Effective Rates of Protection in 1995.

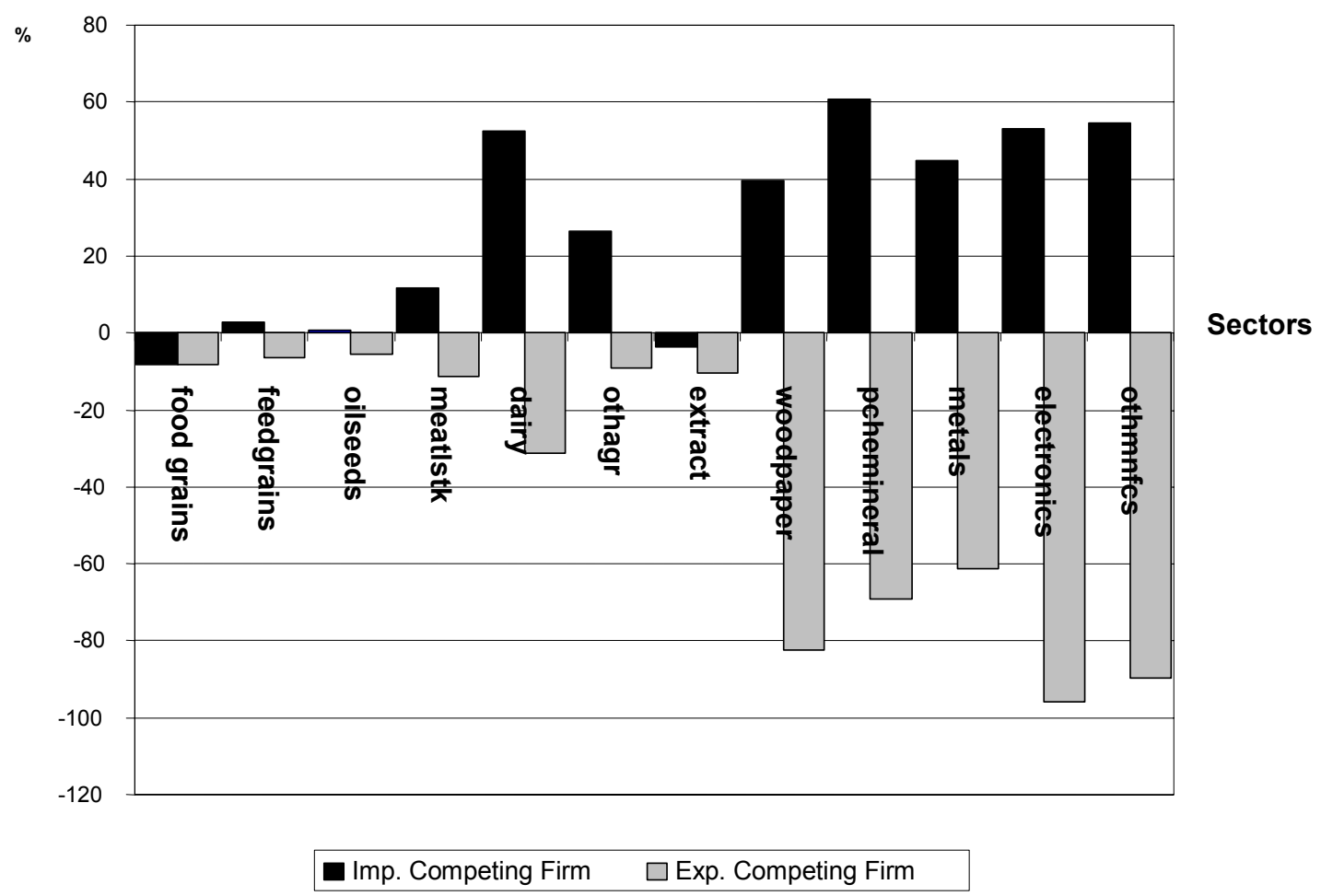

Source: Calculations by Emiko Fukase based on version 4 of GTAP database, 1995 tariff rates. 
Table 1. Key dimensions of version 5 GTAP data (in italics) and modified data for the model with duty drawbacks (shares of GDP)

\begin{tabular}{|c|c|c|c|c|c|}
\hline Regions & $\begin{array}{c}\text { Private } \\
\text { Consumption }\end{array}$ & Investment & $\begin{array}{c}\text { Government } \\
\text { Consumption }\end{array}$ & Exports & Imports \\
\hline \multirow{2}{*}{ North America } & 0.68 & 0.18 & 0.15 & 0.14 & 0.15 \\
\hline & 0.68 & 0.18 & 0.15 & 0.14 & 0.15 \\
\hline \multirow{2}{*}{ Western Europe } & 0.61 & 0.19 & 0.19 & 0.31 & 0.30 \\
\hline & 0.61 & 0.19 & 0.19 & 0.31 & 0.30 \\
\hline \multirow[t]{2}{*}{ Australia/New Zealand } & 0.62 & 0.22 & 0.17 & 0.20 & 0.20 \\
\hline & 0.62 & 0.22 & 0.17 & 0.20 & 0.20 \\
\hline \multirow[t]{2}{*}{ Japan } & 0.60 & 0.29 & 0.10 & 0.12 & 0.10 \\
\hline & 0.60 & 0.29 & 0.10 & 0.12 & 0.10 \\
\hline \multirow[t]{2}{*}{ China } & 0.48 & 0.36 & 0.12 & 0.30 & 0.27 \\
\hline & 0.48 & 0.36 & 0.12 & 0.30 & 0.27 \\
\hline \multirow[t]{2}{*}{ Taiwan } & 0.57 & 0.20 & 0.14 & 0.46 & 0.37 \\
\hline & 0.57 & 0.20 & 0.14 & 0.46 & 0.37 \\
\hline \multirow[t]{2}{*}{ Other NICs } & 0.57 & 0.38 & 0.11 & 0.52 & 0.58 \\
\hline & 0.57 & 0.38 & 0.11 & 0.52 & 0.58 \\
\hline \multirow{2}{*}{ Indonesia } & 0.64 & 0.29 & 0.07 & 0.27 & 0.27 \\
\hline & 0.64 & 0.29 & 0.07 & 0.27 & 0.27 \\
\hline \multirow[t]{2}{*}{ Vietnam } & 0.71 & 0.33 & 0.10 & 0.43 & 0.57 \\
\hline & 0.71 & 0.33 & 0.10 & 0.43 & 0.56 \\
\hline \multirow[t]{2}{*}{ Other Southeast Asia } & 0.55 & 0.34 & 0.11 & 0.61 & 0.61 \\
\hline & 0.55 & 0.34 & 0.11 & 0.61 & 0.61 \\
\hline \multirow[t]{2}{*}{ India } & 0.65 & 0.24 & 0.12 & 0.12 & 0.12 \\
\hline & 0.65 & 0.24 & 0.12 & 0.12 & 0.12 \\
\hline \multirow[t]{2}{*}{ Other South Asia } & 0.76 & 0.19 & 0.09 & 0.17 & 0.21 \\
\hline & 0.76 & 0.19 & 0.09 & 0.17 & 0.21 \\
\hline \multirow[t]{2}{*}{ Brazil } & 0.64 & 0.20 & 0.18 & 0.08 & 0.10 \\
\hline & 0.64 & 0.20 & 0.18 & 0.08 & 0.10 \\
\hline \multirow[t]{2}{*}{ Other Latin America } & 0.75 & 0.21 & 0.08 & 0.19 & 0.22 \\
\hline & 0.75 & 0.21 & 0.08 & 0.19 & 0.22 \\
\hline \multirow[t]{2}{*}{ Turkey } & 0.67 & 0.26 & 0.12 & 0.23 & 0.28 \\
\hline & 0.67 & 0.26 & 0.12 & 0.23 & 0.28 \\
\hline \multirow[t]{2}{*}{ Other Middle East \& N. Africa } & 0.57 & 0.22 & 0.22 & 0.33 & 0.33 \\
\hline & 0.57 & 0.22 & 0.22 & 0.33 & 0.33 \\
\hline \multirow[t]{2}{*}{ Economies in Transition } & 0.64 & 0.22 & 0.16 & 0.31 & 0.32 \\
\hline & 0.64 & 0.22 & 0.16 & 0.31 & 0.32 \\
\hline \multirow[t]{2}{*}{ S. African Customs Union } & 0.59 & 0.18 & 0.21 & 0.26 & 0.24 \\
\hline & 0.59 & 0.18 & 0.21 & 0.26 & 0.24 \\
\hline \multirow[t]{2}{*}{ Other Sub-Saharan Africa } & 0.76 & 0.16 & 0.12 & 0.27 & 0.31 \\
\hline & 0.76 & 0.16 & 0.12 & 0.27 & 0.31 \\
\hline \multirow[t]{2}{*}{ Rest of World } & 0.78 & 0.18 & 0.10 & 0.15 & 0.21 \\
\hline & 0.78 & 0.18 & 0.10 & 0.15 & 0.21 \\
\hline \multirow[t]{2}{*}{ Total } & 0.63 & 0.22 & 0.15 & 0.22 & 0.22 \\
\hline & 0.63 & 0.22 & 0.15 & 0.22 & 0.22 \\
\hline
\end{tabular}

Source: Author's calculations based on version 5 GTAP data and modified GTAP data for the model with duty drawbacks. 
Table 2. Distribution of Imported Intermediates Use by Sector in China (\%)

\begin{tabular}{|c|c|c|c|c|c|c|}
\hline & \multicolumn{2}{|c|}{$\begin{array}{l}\text { Model with duty } \\
\text { drawbacks }\end{array}$} & \multicolumn{2}{|c|}{ GTAP } & \multicolumn{2}{|c|}{$\begin{array}{l}\text { Model with duty } \\
\text { drawbacks }\end{array}$} \\
\hline & \multicolumn{2}{|c|}{$\begin{array}{c}\text { Share in total import use } \\
\text { of }\end{array}$} & \multirow[b]{2}{*}{ All firms } & \multirow[b]{2}{*}{ All firms } & \multicolumn{2}{|c|}{$\begin{array}{c}\text { Share in sectoral import } \\
\text { use of }\end{array}$} \\
\hline & $\begin{array}{l}\text { Export- } \\
\text { oriented } \\
\text { frims }\end{array}$ & $\begin{array}{c}\text { Domestic } \\
\text { oriented } \\
\text { firms }\end{array}$ & & & $\begin{array}{c}\text { Export- } \\
\text { oriented } \\
\text { firms }\end{array}$ & $\begin{array}{l}\text { Domestic } \\
\text { oriented } \\
\text { firms }\end{array}$ \\
\hline Rice & 0.0 & 0.7 & 0.5 & 0.6 & 1 & 99 \\
\hline Wheat & 0.0 & 0.2 & 0.2 & 0.2 & 0 & 100 \\
\hline Feedgrains & 0.2 & 0.5 & 0.4 & 0.4 & 12 & 88 \\
\hline Vegetables-fruits & 0.1 & 1.8 & 1.3 & 1.4 & 2 & 98 \\
\hline Oilseeds & 0.0 & 0.1 & 0.1 & 0.1 & 5 & 95 \\
\hline Sugar & 0.0 & 0.0 & 0.0 & 0.0 & 12 & 88 \\
\hline Plantfibers & 0.0 & 0.7 & 0.5 & 0.5 & 0 & 100 \\
\hline Livestock-meat & 0.3 & 1.7 & 1.3 & 1.3 & 6 & 94 \\
\hline Dairy & 0.0 & 0.0 & 0.0 & 0.0 & 4 & 96 \\
\hline Other food & 0.7 & 1.6 & 1.3 & 1.4 & 17 & 83 \\
\hline Beverages-tobacco & 0.2 & 1.1 & 0.8 & 0.8 & 6 & 94 \\
\hline Extract & 0.6 & 3.0 & 2.3 & 2.4 & 8 & 92 \\
\hline Textiles & 6.5 & 7.5 & 7.2 & 7.1 & 27 & 73 \\
\hline Apparel & 7.3 & 1.7 & 3.4 & 2.5 & 65 & 35 \\
\hline Light manufactures & 5.1 & 1.0 & 2.2 & 1.7 & 69 & 31 \\
\hline Petrochemicals & 4.9 & 17.6 & 13.8 & 14.1 & 11 & 89 \\
\hline Metals & 2.4 & 7.5 & 6.0 & 6.1 & 12 & 88 \\
\hline Autos & 0.4 & 2.0 & 1.5 & 1.6 & 8 & 92 \\
\hline Electronics & 17.5 & 6.7 & 9.9 & 9.2 & 53 & 47 \\
\hline Other manufactures & 15.3 & 18.4 & 17.5 & 16.9 & 26 & 74 \\
\hline Trade-transport & 2.4 & 6.4 & 5.2 & 5.2 & 14 & 86 \\
\hline Construction & 0.1 & 7.0 & 4.9 & 5.2 & 0 & 100 \\
\hline Communication & 0.1 & 0.7 & 0.5 & 0.5 & 3 & 97 \\
\hline Commercial services & 0.2 & 2.5 & 1.8 & 1.9 & 3 & 97 \\
\hline Other services & 0.2 & 8.5 & 6.0 & 6.4 & 1 & 99 \\
\hline Capital goods & 35.4 & 1.0 & 11.4 & 12.6 & 94 & 6 \\
\hline Total & 100.0 & 100.0 & 100.0 & 100.0 & 30 & 70 \\
\hline
\end{tabular}


Table 3. China's Shares of World Output, Exports and Imports in 1997 (Percent)

\begin{tabular}{lcccccc}
\hline & \multicolumn{2}{c}{ Output } & \multicolumn{2}{c}{ Exports } & \multicolumn{2}{c}{ Imports } \\
\cline { 2 - 7 } & GTAP & Modelwith & GTAP & Model with & GTAP & Model with \\
\hline Rice & 19.3 & 18.8 & 6.2 & 6.2 & 3.1 & 2.8 \\
Wheat & 10.7 & 10.5 & 0.1 & 0.1 & 3.1 & 2.9 \\
Feedgrains & 9.0 & 8.9 & 6.1 & 6.1 & 3.1 & 3.0 \\
Vegetables \& fruits & 17.7 & 17.3 & 2.9 & 2.9 & 1.3 & 1.2 \\
Oilseeds & 8.5 & 8.4 & 1.8 & 1.8 & 8.3 & 7.9 \\
Sugar & 1.1 & 1.1 & 1.3 & 1.3 & 2.0 & 1.9 \\
Plantfibers & 15.0 & 14.4 & 0.0 & 0.0 & 13.2 & 12.3 \\
Livestock \& meat & 8.8 & 8.6 & 3.9 & 3.9 & 2.9 & 2.6 \\
Dairy & 0.6 & 0.6 & 0.2 & 0.2 & 0.7 & 0.7 \\
Processed food & 3.4 & 3.4 & 3.2 & 3.2 & 3.2 & 3.1 \\
Beverages \& tobacco & 6.7 & 6.5 & 2.1 & 2.1 & 2.6 & 2.7 \\
Extract & 8.5 & 8.4 & 1.5 & 1.5 & 2.1 & 2.0 \\
Textiles & 15.7 & 14.9 & 10.8 & 10.6 & 10.6 & 11.4 \\
Apparel & 9.7 & 9.6 & 18.7 & 18.7 & 1.5 & 1.6 \\
Light manufactures & 18.7 & 18.2 & 27.6 & 27.4 & 3.4 & 3.8 \\
Petrochemicals & 7.5 & 7.4 & 2.9 & 2.9 & 5.0 & 4.9 \\
Metals & 6.9 & 6.8 & 3.3 & 3.3 & 4.4 & 4.2 \\
Automobiles & 2.1 & 2.1 & 0.3 & 0.3 & 1.0 & 0.9 \\
Electronics & 4.5 & 4.3 & 4.5 & 4.4 & 4.2 & 4.3 \\
Other manufactures & 6.4 & 6.3 & 4.2 & 4.2 & 3.9 & 3.7 \\
Trade \& transport & 2.3 & 2.2 & 3.3 & 3.3 & 2.7 & 2.5 \\
Construction & 5.0 & 5.0 & 1.5 & 1.5 & 4.1 & 3.8 \\
Communications & 2.4 & 2.4 & 1.3 & 1.3 & 1.4 & 1.3 \\
Commercial Services & 0.9 & 0.9 & 0.5 & 0.5 & 0.9 & 0.9 \\
Other services & 2.0 & 2.0 & 0.8 & 0.8 & 1.5 & 1.4 \\
Total & 4.1 & 4.0 & 3.9 & 3.8 & 3.5 & 3.5 \\
\hline Sorcesyyyyyyy & & & & & \\
\end{tabular}

Source: Author's calculations with GTAP and the model with duty drawbacks (DD). 
Table 4. Pre- and post-accession import protection (tariff or tariff equivalent)

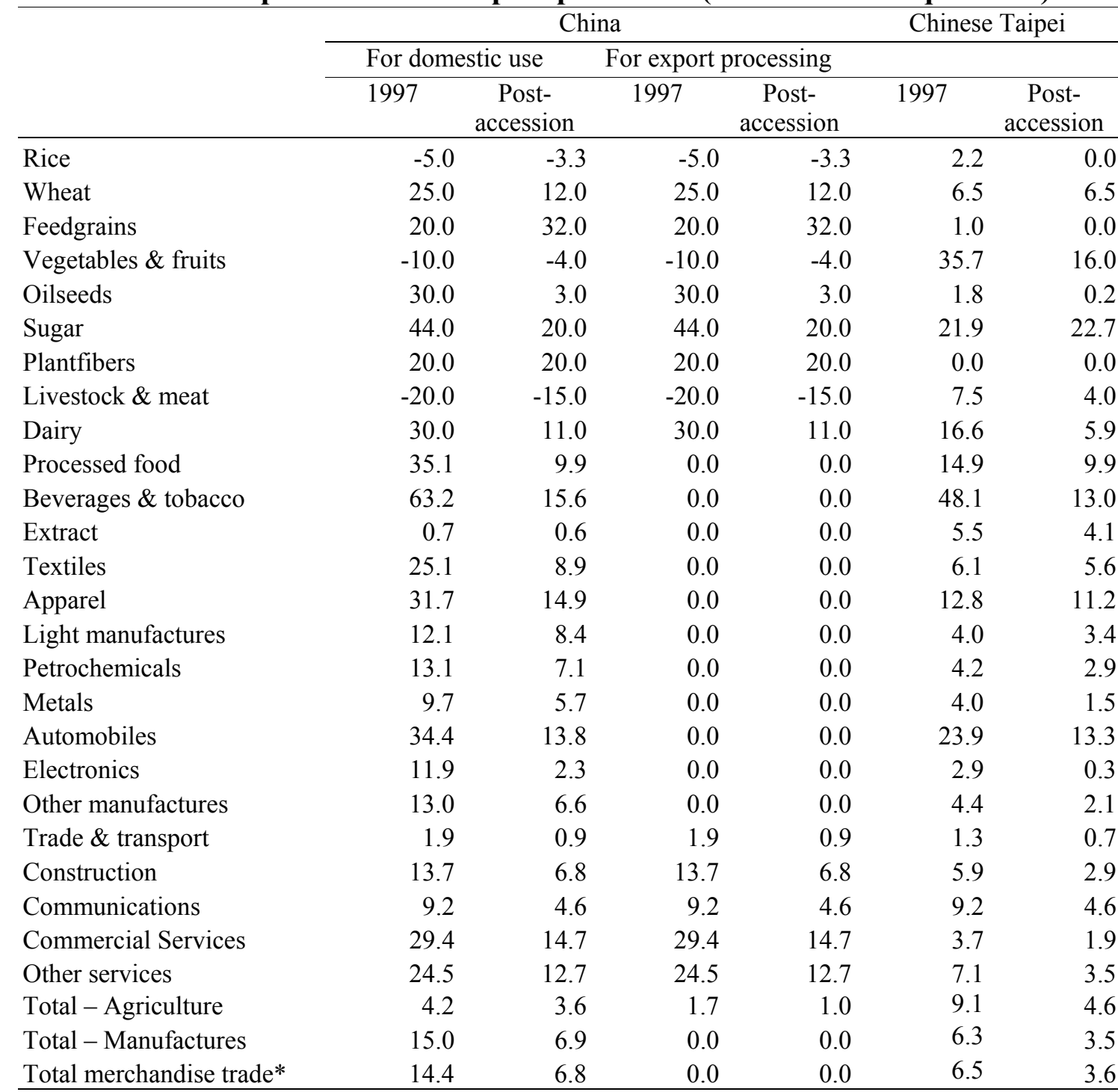

Source: Version 5 GTAP for protection in 1997 and Ianchovichina and Martin (2003) for post-accession protection. *The estimates in the table are based on trade weights for the respective years. If trade weights for 2000 at the sixdigit level of the harmonized system are used the total weighted average tariffs in 2001 and 2007 are $12.2 \%$ and $6.3 \%$, respectively, for China, and $4.5 \%$ and $3.1 \%$, respectively, for Chinese Taipei. 
Table 5. Impact of Accession on Output, Exports and Imports (\% changes)

\begin{tabular}{|c|c|c|c|c|c|c|c|c|c|}
\hline & \multicolumn{3}{|c|}{ Output } & \multicolumn{3}{|c|}{ Exports } & \multicolumn{3}{|c|}{ Imports } \\
\hline & \multicolumn{3}{|c|}{ Model } & \multicolumn{3}{|c|}{ Model } & \multicolumn{3}{|c|}{ Model } \\
\hline & GTAP & with DD & Bias* & GTAP & with DD & Bias & GTAP & with DD & Bias \\
\hline Rice & -1.9 & -1.6 & -0.3 & -7.5 & -4.0 & -3.6 & -6.9 & -8.7 & 2.0 \\
\hline Wheat & -10.9 & -9.9 & -1.1 & 19.9 & 21.9 & -1.6 & 29.1 & 28.9 & 0.2 \\
\hline Feedgrains & -4.6 & -4.7 & 0.1 & -77.9 & -77.6 & -1.3 & -15.7 & -16.5 & 1.0 \\
\hline Vegetables \& fruits & -3.9 & -3.4 & -0.5 & 1.9 & 3.0 & -1.1 & -20.5 & -21.5 & 1.3 \\
\hline Oilseeds & -15.1 & -14.3 & -0.9 & 26.0 & 27.8 & -1.4 & 42.8 & 44.7 & -1.3 \\
\hline Sugar & -12.4 & -11.0 & -1.6 & 5.5 & 7.5 & -1.9 & 38.8 & 37.8 & 0.7 \\
\hline Plantfibers & 16.6 & 15.8 & 0.7 & -55.5 & -56.0 & 1.1 & 15.8 & 13.6 & 1.9 \\
\hline Livestock \& meat & 2.6 & 2.5 & 0.1 & 4.4 & 1.8 & 2.6 & -26.2 & -27.9 & 2.4 \\
\hline Dairy & -8.1 & -7.3 & -0.9 & 7.3 & 6.3 & 0.9 & 65.3 & 64.2 & 0.7 \\
\hline Processed food & -17.6 & -16.0 & -1.9 & 13.8 & 12.8 & 0.9 & 116.5 & 106.0 & 5.1 \\
\hline Beverages \& tobacco & -19.4 & -17.5 & -2.3 & 9.9 & 0.5 & 9.4 & 566.3 & 453.6 & 20.4 \\
\hline Extract & -1.9 & -1.5 & -0.4 & 10.0 & 7.5 & 2.3 & -8.0 & -7.9 & -0.1 \\
\hline Textiles & 17.8 & 16.7 & 0.9 & 38.8 & 27.2 & 9.1 & 92.3 & 63.7 & 17.5 \\
\hline Apparel & 96.2 & 81.2 & 8.3 & 213.6 & 177.3 & 13.1 & 154.7 & 120.4 & 15.6 \\
\hline Light manufactures & -0.2 & 0.0 & -0.2 & 2.8 & 0.9 & 1.9 & 29.9 & 12.0 & 16.0 \\
\hline Petrochemicals & -4.0 & -3.4 & -0.6 & 1.0 & -0.6 & 1.6 & 17.2 & 13.2 & 3.5 \\
\hline Metals & -6.4 & -4.8 & -1.7 & -0.7 & -0.4 & -0.3 & 15.4 & 11.4 & 3.6 \\
\hline Automobiles & 16.5 & 15.7 & 0.7 & 440.1 & 391.4 & 9.9 & 43.1 & 34.7 & 6.2 \\
\hline Electronics & 5.0 & -3.9 & 9.3 & 28.4 & 2.0 & 25.9 & 22.2 & 6.2 & 15.1 \\
\hline Other manufactures & -6.2 & -4.2 & -2.1 & 1.9 & -1.4 & 3.3 & 27.0 & 14.2 & 11.2 \\
\hline Trade \& transport & -0.3 & -0.1 & -0.2 & -2.5 & -2.1 & -0.4 & 4.0 & 2.2 & 1.8 \\
\hline Construction & 0.7 & 0.4 & 0.3 & -3.5 & -2.0 & -1.5 & 22.2 & 19.4 & 2.3 \\
\hline Communications & -1.1 & -0.8 & -0.3 & -8.3 & -6.7 & -1.7 & 16.7 & 14.2 & 2.2 \\
\hline Commercial Services & -2.9 & -2.5 & -0.4 & -9.3 & -7.0 & -2.5 & 41.3 & 38.6 & 1.9 \\
\hline Other services & -1.0 & -0.8 & -0.2 & -4.4 & -3.6 & -0.8 & 40.5 & 37.6 & 2.1 \\
\hline Capital goods & 1.1 & 0.7 & 0.4 & $\mathrm{~N} / \mathrm{A}$ & N/A & N/A & N/A & N/A & N/A \\
\hline Total & 2.3 & 1.8 & 0.5 & 32.4 & 22.8 & 7.8 & 32.3 & 22.5 & 8.0 \\
\hline
\end{tabular}

Source: Author's simulations with GTAP and the model with duty drawbacks (DD).

* The bias is computed as a difference in percentage changes, namely $\left[(1+\mathrm{x}) /\left(1+\mathrm{x} \_\mathrm{DD}\right)-1\right]^{*} 100$, where $\mathrm{x}$ is the percentage change in the respective variable in GTAP and x_DD is the percentage change in the respective variable in the model with duty drawbacks. 
Table 6. Welfare Changes due to China's WTO Accession* (\$US Millions)

\begin{tabular}{|c|c|c|c|c|}
\hline & GTAP & $\begin{array}{c}\text { Model } \\
\text { with DD }\end{array}$ & \multirow{3}{*}{\multicolumn{2}{|c|}{$\begin{array}{l}\text { Contribution to the Difference } \\
\text { between GTAP and model with DD: } \\
\text { Allocative Efficiency Gains in China } \\
\text { by Product: }\end{array}$}} \\
\hline North America & 4384 & 3480 & & \\
\hline Western Europe & 7345 & 6009 & & \\
\hline Australia and New Zealand & 103 & 40 & & $\%$ \\
\hline Japan & 2394 & 1513 & Agriculture & 0.1 \\
\hline China & 10317 & 8970 & Processed food & 4.0 \\
\hline Taiwán, China & 592 & 337 & Beverages \& tobacco & 0.1 \\
\hline Other NICs & 1249 & 734 & Extract & -0.5 \\
\hline Indonesia & -313 & -286 & Textiles & 45.9 \\
\hline Vietnam & -93 & -83 & Apparel & 23.2 \\
\hline Other Southeast Asia & -466 & -411 & Light manufactures & 1.0 \\
\hline India & -716 & -625 & Petrochemicals & 1.9 \\
\hline Other South Asia & -808 & -718 & Metals & -1.6 \\
\hline Brazil & 1214 & 1068 & Automobiles & 3.8 \\
\hline Other Latin America & -542 & -516 & Electronics & 13.4 \\
\hline Turkey & -281 & -252 & Other manufactures & 11.2 \\
\hline Other Middle East \& N. Africa & -371 & -409 & Trade \& transport & -0.9 \\
\hline Economies in Transition & -190 & -239 & Construction & 0.4 \\
\hline South African Customs Union & 24 & 3 & Communications & -0.1 \\
\hline Other Sub-Saharan Africa & -84 & -89 & Commercial Services & -1.5 \\
\hline Rest of World & -178 & -182 & Other services & -0.3 \\
\hline Total & 23580 & 18344 & Total & 100.0 \\
\hline
\end{tabular}

Source: Author's simulations with GTAP and the model with duty drawbacks.

*These are welfare changes due to reforms implemented between 1997 and 2007. 
Table 7. Distribution of Imported Intermediates Use in China: A Comparison (\%)

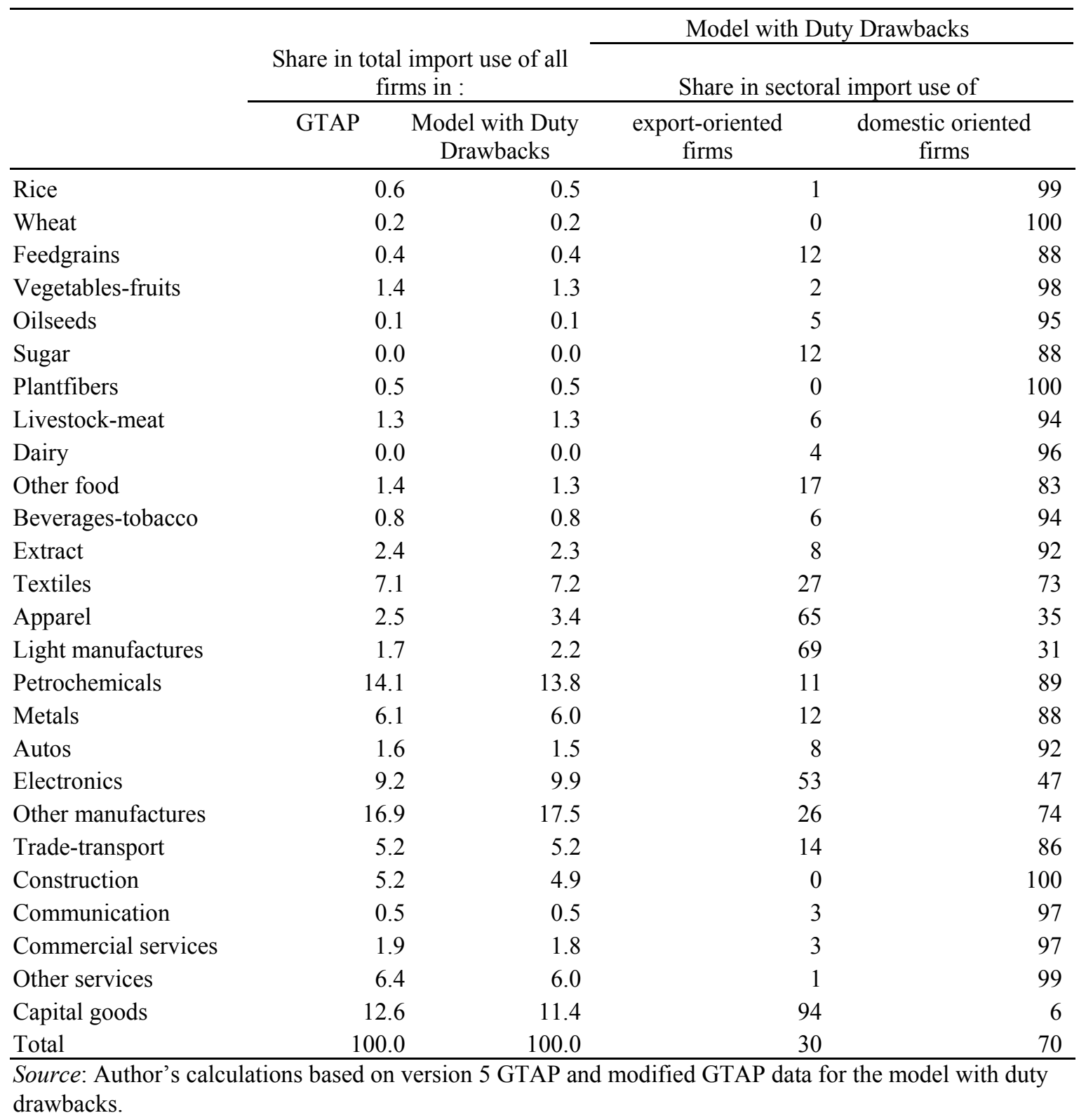


Table 8. China's import protection (tariff or tariff equivalent)

\begin{tabular}{|c|c|c|c|c|c|c|c|c|}
\hline & \multicolumn{2}{|c|}{ For domestic use } & \multicolumn{2}{|c|}{$\begin{array}{l}\text { For export } \\
\text { processing }\end{array}$} & \multicolumn{2}{|c|}{ For domestic use } & \multicolumn{2}{|c|}{$\begin{array}{l}\text { For export } \\
\text { processing }\end{array}$} \\
\hline & 1997 & $\begin{array}{c}\text { Post- } \\
\text { accession }\end{array}$ & 1997 & $\begin{array}{c}\text { Post- } \\
\text { accession }\end{array}$ & 1995 & $\begin{array}{c}\text { Post- } \\
\text { accession }\end{array}$ & 1995 & $\begin{array}{c}\text { Post- } \\
\text { accession }\end{array}$ \\
\hline Rice & -5.0 & -3.3 & -5.0 & -3.3 & -5.0 & -3.3 & -5.0 & -3.3 \\
\hline Wheat & 25.0 & 12.0 & 25.0 & 12.0 & 25.0 & 12.0 & 25.0 & 12.0 \\
\hline Feedgrains & 20.0 & 32.0 & 20.0 & 32.0 & 20.0 & 32.0 & 20.0 & 32.0 \\
\hline Vegetables \& fruits & -10.0 & -4.0 & -10.0 & -4.0 & -10.0 & -4.0 & -10.0 & -4.0 \\
\hline Oilseeds & 30.0 & 3.0 & 30.0 & 3.0 & 30.0 & 3.0 & 30.0 & 3.0 \\
\hline Sugar & 44.0 & 20.0 & 44.0 & 20.0 & 44.0 & 20.0 & 44.0 & 20.0 \\
\hline Plantfibers & 20.0 & 20.0 & 20.0 & 20.0 & 20.0 & 20.0 & 20.0 & 20.0 \\
\hline Livestock \& meat & -20.0 & -15.0 & -20.0 & -15.0 & -20.0 & -15.0 & -20.0 & -15.0 \\
\hline Dairy & 30.0 & 11.0 & 30.0 & 11.0 & 30.0 & 11.0 & 30.0 & 11.0 \\
\hline Processed food & 35.1 & 9.9 & 0.0 & 0.0 & 20.1 & 9.9 & 0.0 & 0.0 \\
\hline Beverages \& tobacco & 63.2 & 15.6 & 0.0 & 0.0 & 137.2 & 15.6 & 0.0 & 0.0 \\
\hline Extract & 0.7 & 0.6 & 0.0 & 0.0 & 3.4 & 0.6 & 0.0 & 0.0 \\
\hline Textiles & 25.1 & 8.9 & 0.0 & 0.0 & 56.0 & 8.9 & 0.0 & 0.0 \\
\hline Apparel & 31.7 & 14.9 & 0.0 & 0.0 & 76.1 & 14.9 & 0.0 & 0.0 \\
\hline Light manufactures & 12.1 & 8.4 & 0.0 & 0.0 & 32.3 & 8.4 & 0.0 & 0.0 \\
\hline Petrochemicals & 13.1 & 7.1 & 0.0 & 0.0 & 20.2 & 7.1 & 0.0 & 0.0 \\
\hline Metals & 9.7 & 5.7 & 0.0 & 0.0 & 17.4 & 5.7 & 0.0 & 0.0 \\
\hline Automobiles & 34.4 & 13.8 & 0.0 & 0.0 & 123.1 & 13.8 & 0.0 & 0.0 \\
\hline Electronics & 11.9 & 2.3 & 0.0 & 0.0 & 24.4 & 2.3 & 0.0 & 0.0 \\
\hline Other manufactures & 13.0 & 6.6 & 0.0 & 0.0 & 22.0 & 6.6 & 0.0 & 0.0 \\
\hline Trade \& transport & 1.9 & 0.9 & 1.9 & 0.9 & 1.9 & 0.9 & 1.9 & 0.9 \\
\hline Construction & 13.7 & 6.8 & 13.7 & 6.8 & 13.7 & 6.8 & 13.7 & 6.8 \\
\hline Communications & 9.2 & 4.6 & 9.2 & 4.6 & 9.2 & 4.6 & 9.2 & 4.6 \\
\hline Commercial Services & 29.4 & 14.7 & 29.4 & 14.7 & 29.4 & 14.7 & 29.4 & 14.7 \\
\hline Other services & 24.5 & 12.7 & 24.5 & 12.7 & 24.5 & 12.7 & 24.5 & 12.7 \\
\hline Total - Agriculture & 4.2 & 3.6 & 1.7 & 1.0 & 4.8 & 3.6 & 1.7 & 1.0 \\
\hline Total - Manufactures & 15.0 & 6.9 & 0.0 & 0.0 & 25.3 & 6.9 & 0.0 & 0.0 \\
\hline Total merchandise trade* & 14.4 & 6.8 & 0.0 & 0.0 & 24.3 & 6.8 & 0.0 & 0.0 \\
\hline
\end{tabular}

Source: versions 4 and 5 GTAP for protection in 1995 and 1997, respectively, and Ianchovichina and Martin (2003) for post-accession protection.

*The estimates in the table are based on trade weights for the respective years. 
Table 9. Impact of WTO Accession - Liberalization from 1995 Tariffs (\% changes)

\begin{tabular}{|c|c|c|c|c|c|c|c|c|c|}
\hline & \multicolumn{3}{|c|}{ Output } & \multicolumn{3}{|c|}{ Exports } & \multicolumn{3}{|c|}{ Imports } \\
\hline & \multicolumn{3}{|c|}{ Model with } & \multicolumn{3}{|c|}{ Model with } & \multicolumn{3}{|c|}{ Model with } \\
\hline & GTAP & DD & Bias & GTAP & DD & Bias & GTAP & DD & Bias \\
\hline Rice & -3.1 & -2.2 & -0.9 & -11.0 & 7.8 & -17.4 & -4.2 & -13.2 & 10.4 \\
\hline Wheat & -8.5 & -5.1 & -3.6 & 6.6 & 22.3 & -12.8 & 43.5 & 37.7 & 4.2 \\
\hline Feedgrains & -3.9 & -3.3 & -0.6 & -79.3 & -77.0 & -10.0 & -15.7 & -18.8 & 3.8 \\
\hline Vegetables \& fruits & -5.1 & -3.7 & -1.5 & 0.2 & 12.0 & -10.5 & -23.0 & -27.5 & 6.2 \\
\hline Oilseeds & -13.6 & -10.2 & -3.8 & 14.1 & 28.5 & -11.2 & 58.3 & 61.1 & -1.7 \\
\hline Sugar & -15 & -9.7 & -5.9 & 1.4 & 16.4 & -12.9 & 41.5 & 36.2 & 3.9 \\
\hline Plantfibers & 7.3 & 8.8 & -1.4 & -46.7 & -45.9 & -1.5 & 5.3 & 1.6 & 3.6 \\
\hline Livestock \& meat & 3 & 3.5 & -0.5 & -7.6 & 9.8 & -15.8 & -18.9 & -28.1 & 12.8 \\
\hline Dairy & -6.9 & -3.7 & -3.3 & -0.8 & 16.2 & -14.6 & 77.1 & 67.8 & 5.5 \\
\hline Processed food & -6.5 & -1.8 & -4.8 & 7.8 & 23.2 & -12.5 & 33.7 & 23.6 & 8.2 \\
\hline Beverages \& tobacco & -65.7 & -58.6 & -17.1 & 36.3 & 21.2 & 12.5 & 2409.3 & 1425.3 & 64.5 \\
\hline Extract & -2.9 & -0.9 & -2.0 & 23.2 & 18.0 & 4.4 & -2.5 & -3.6 & 1.1 \\
\hline Textiles & 7.5 & 8.4 & -0.8 & 92.9 & 49.4 & 29.1 & 231.5 & 99.1 & 66.5 \\
\hline Apparel & 142.4 & 91 & 26.9 & 378.0 & 242.6 & 39.5 & 804.1 & 478.1 & 56.4 \\
\hline Light manufactures & 4.8 & 6.1 & -1.2 & 36.5 & 19.7 & 14.0 & 234.0 & 53.2 & 118.0 \\
\hline Petrochemicals & -6.4 & -3.7 & -2.8 & 12.3 & 14.9 & -2.3 & 35.5 & 22.9 & 10.3 \\
\hline Metals & -11.1 & -5.2 & -6.2 & 16.1 & 24.7 & -6.9 & 44.7 & 27.2 & 13.8 \\
\hline Automobiles & 3.8 & -21.4 & 32.1 & 1526.2 & 560.8 & 146.1 & 428.3 & 167.7 & 97.3 \\
\hline Electronics & 28.6 & 1.4 & 26.8 & 97.6 & 21.9 & 62.1 & 58.2 & 19.1 & 32.8 \\
\hline Other manufactures & -8.7 & -4.2 & -4.7 & 22.6 & 20.6 & 1.7 & 59.2 & 36.7 & 16.5 \\
\hline Trade \& transport & 0.6 & 1.6 & -1.0 & 4.6 & 10.6 & -5.4 & 1.9 & -7.2 & 9.8 \\
\hline Construction & 2.3 & 1.7 & 0.6 & 3.9 & 16.9 & -11.1 & 19.7 & 8.3 & 10.5 \\
\hline Communications & -0.9 & -0.1 & -0.8 & -5.6 & 8.0 & -12.6 & 15.1 & 3.1 & 11.6 \\
\hline Commercial Services & -2.6 & -1.3 & -1.3 & -8.6 & 7.4 & -14.9 & 40.8 & 27.2 & 10.7 \\
\hline Other services & -0.8 & -0.3 & -0.5 & 2.0 & 13.1 & -9.8 & 37.1 & 23.0 & 11.5 \\
\hline Capital goods & 2.7 & 1.9 & 0.8 & N/A & N/A & N/A & N/A & N/A & $\mathrm{N} / \mathrm{A}$ \\
\hline Total & 5.5 & 3.6 & 1.8 & 78.7 & 47.2 & 21.4 & 75.8 & 46.0 & 20.4 \\
\hline
\end{tabular}

Source: Author's simulations with GTAP and the model with duty drawbacks (DD). 
Table 10. Welfare Changes due to China's WTO Accession* - Liberalization from 1995 Tariffs (\$US Millions)

\begin{tabular}{lrr}
\hline & GTAI & Model with DD \\
\hline North America & 7576 & 4488 \\
Western Europe & 14506 & 9634 \\
Australia and New Zealand & 386 & 109 \\
Japan & 6550 & 3759 \\
China & 27710 & 18891 \\
Taiwán, China & 2529 & 1559 \\
Other NICs & 5432 & 3197 \\
Indonesia & -503 & -376 \\
Vietnam & -168 & -114 \\
Other Southeast Asia & -792 & -599 \\
India & -1057 & -763 \\
Other South Asia & -1185 & -841 \\
Brazil & 94 & -14 \\
Other Latin America & -520 & -550 \\
Turkey & -416 & -310 \\
Other Middle East \& North Africa & -171 & -462 \\
Economies in Transition & -16 & -283 \\
South African Customs Union & 90 & 10 \\
Other Sub-Saharan Africa & -39 & -97 \\
Rest of World & -89 & -133 \\
Total & 59918 & 37104 \\
\hline Sourc: Aut &
\end{tabular}

Source: Author's simulations with GTAP and the model with DD.

*These are welfare changes due to reforms implemented between 1995 and 2007. 